\title{
Beban Kerja Wanita Miskin Di Kecamatan Pundong Bantul
}

\author{
M. Agus Prayudi \\ Akademi Pariwisata Indraphrasta Yogyakarta \\ E-mail : akpar.indraphrasta@yahoo.com
}

\begin{abstract}
Women play great role in household life. Sometime, their working hour cannot be calculated. However, it should not be assessed with the extent of expenditure that should be made to finance work of housewife, which must be a woman, especially the poor one. This research was intended to describe weekly time usage of poor women in doing household activity and to describe average weekly workload that the poor women should do. The conclusion of the research is as follow. (1) Household works the poor women did in Pundong district were cooking (100\%), washing (100\%), preparing husband's need (95.5\%), caring children (86.7\%), and cleaning rooms (84.4\%). Caring children was done for 40 hour 42 minutes a week while preparing husband's need was done for 15 hours 6 minutes a week. Job sectors that the poor women should do in Pundong district were agricultural sector, planting and trading backyard harvest (71.1\%) with duration of 17 hour 24 minutes; animal husbandry sector by selling animal yield (75.6\%) with duration of 12 hour 42 minutes; social sector including aiding neighbor's work (86.7\%) and religious activity that covered 7 hour 42 minutes. In economic field, activity mostly done was service sector as agricultural worker or non agricultural worker based on other's order (57.8\%). Time used mostly was to work as private employee (34 hour 12 minutes).
\end{abstract}

Keyword: workload, women, poor

Abstrak: Wanita mempunyai peranan yang besar dalam kehidupan rumah tangga. Kadang waktu kerjanya tidak dapat diperhitungkan banyaknya, namun tidak perlu dihargai dengan seberapa besar yang harus dikeluarkan untuk membiayai pekerjaan seorang ibu rumah tangga yang notabene adalah wanita. Terlebih wanita miskin, maka pada penelitian ini bertujuan untuk: (1) Mendeskripsikan penggunaan waktu wanita miskin untuk melaksanakan kegiatan rumah tangga per minggu, (2) Mendeskripsikan beban kerja yang harus dilakukan wanita miskin rata-rata per minggu. Kesimpulan penelitian ini adalah sebagai berikut : (1) Pola pekerjaan rumah tangga yang dijalankan oleh wanita miskin di kecamatan Pundong adalah memasak (100\%), mencuci pakaian (100\%), menyiapkan keperluan suami $(95,5 \%)$, mengasuh anak $(86,7 \%)$, membersihkan kamar $(84,4 \%)$, mengasuh anak 40 jam 42 menit dan mempersiapkan keperluan suami 15 jam 6 menit per minggu. (2) Bidang pekerjaan yang menjadi beban bagi wanita miskin di kecamatan Pundong adalah bidang pertanian, menanam dan memperdagangkan hasil tanaman pekarangan $(71,1 \%)$, waktu yang diperlukan 17 jam 24 menit, bidang peternakan, menjual hasil ternak $(75,6 \%)$, waktu yang diperlukan untuk pengobatan ternak 12 jam 42 menit, bidang sosial, membantu pekerjaan tetangga $(86,7 \%)$ dan kegiatan keagamaan yakni 7 jam 42 menit, bidang ekonomi, yang paling banyak dijalankan adalah bidang jasa yakni sebagai buruh baik buruh pertanian maupun pekerjaan lainnya yang ditugaskan oleh orang lain $(57,8 \%)$. Waktu yang banyak digunakan adalah untuk bekerja sebagai karyawan swasta (34 jam 12 menit).

Kata kunci: Beban kerja, wanita, dan miskin.

\subsection{Latar Belakang}

Menurut Agnes (Harian Kompas, 21 Juli 2014) persoalan keluarga miskin tidak bisa dipisahkan dari perempuan atau wanita. Oleh karena itu, untuk mengatasi kemiskinan terstruktur, perempuan atau wanita dirangkul, lalu dilatih, dimodali, dan didampingi hingga menjadi wirausaha mandiri agar kelak tidak lagi sekedar memainkan peran pembantu.

Permasalahan kemiskinan di Indonesia terus menjadi sorotan. Laporan Oxfam dan International NGO Forum on Indonesia Development (INVID) menobatkan Indonesia sebagai negara keenam terburuk di dunia untuk ketimpangan ekonomi (Harian Media
Indonesia, 5 Maret 2017). Peranan wanita, perlu dikemukakan untuk ikut mendorong pengentasan kemiskinan. Walikota Surabaya, Tri Rismaharini dalam Agnes (Harian Kompas, 21 Juli 2014), menyatakan jika suami sudah bekerja, tetapi masih miskin, istri digerakkan untuk ikut menopang ekonomi keluarga. Wanita, sebagai istri pada keluarga miskin, mempunyai beban bekerja menopang kebutuhan keluarga.

Dalam Undang-undang Nomor 6 Tahun 2014 tentang desa (Harian Media Indonesia, 15 Desember 2015), wanita diberi ruang partisipasi aktif dalam pembangunan desa. Namun ternyata, partisipasi wanita dalam 
pembangunan perekonomian desa masih rendah. Padahal sebetulnya wanita sebagai warga desa yang jumlahnya cukup signifikan juga mendukung berjalannya perekonomian desa seperti mengelola ternak dan sawah, termasuk industri rumah tangga dan perdagangan. Begitu juga wanita cukup berperan dalam menopang ekonomi keluarga, walaupun kondisi keluarga termasuk keluarga miskin.

Padahal kalau dilihat di lapangan, walaupun pemerintah telah melakukan banyak upaya penanggulangan kemiskinan, namun hasilnya juga belum memuaskan. Program kegiatan penanggulangan kemiskinan oleh Pemerintah kabupaten Bantul dari tahun ke tahun kenaikannya tidak begitu signifikan, seperti tampak pada statistik di bawah ini :

Tabel 1. Presentase KK Miskin di Kabupaten Bantul 2013-2015

\begin{tabular}{|l|c|c|c|}
\hline Tahun & $\begin{array}{c}\text { Jumlah } \\
\text { KK Total }\end{array}$ & $\begin{array}{c}\text { Jumlah } \\
\text { KK } \\
\text { Miskin }\end{array}$ & $\%$ \\
\hline 2013 & 256.463 & 41.480 & 16,17 \\
\hline 2014 & 258.294 & 40.321 & 15,61 \\
\hline 2015 & 273.563 & 40.551 & 14,82 \\
\hline
\end{tabular}

Sumber : BKK PP dan KB Kabupaten Bantul 2016 (http://tkpk.bantulkab.go.id/p=82).

Berdasarkan data pada tabel 1, tingkat keberhasilan pemerintah dalam menurunkan jumlah KK miskin hanya sebesar $1 \%$ per tahun. Sampai dengan tahun 2015 dari jumlah seluruh KK sebanyak 273.563, masih terdapat KK Miskin sebesar 40.551 atau terdapat $15 \%$ dari total KK tergolong KK Miskin.

Tabel 2. Presentase Keluarga Miskin se Kabupaten Bantul tahun 2015.

\begin{tabular}{|l|l|r|r|c|}
\hline No & \multicolumn{1}{|c|}{ Kecamatan } & $\begin{array}{c}\text { KK } \\
\text { Total }\end{array}$ & $\begin{array}{c}\text { KK } \\
\text { Miskin }\end{array}$ & $\%$ \\
\hline 1 & Kretek & 9.659 & 1.542 & 15,96 \\
\hline 2 & Sanden & 10.054 & 1.322 & 13,15 \\
\hline 3 & Srandakan & 9.150 & 1.267 & 3,85 \\
\hline 4 & Pandak & 15.621 & 2.641 & 16,91 \\
\hline 5 & Bambanglipuro & 12.381 & 1.604 & 12,96 \\
\hline 6 & Pundong & 10.367 & 1.968 & 18,98 \\
\hline 7 & Imogiri & 20.571 & 3.278 & 15,94 \\
\hline 8 & Dlingo & 12.062 & 2.405 & 19,94 \\
\hline 9 & Jetis & 17.552 & 3.100 & 17,66 \\
\hline 10 & Bantul & 17.959 & 2.010 & 11,19 \\
\hline 11 & Pajangan & 9.741 & 1.528 & 15,69 \\
\hline 12 & Sedayu & 16.152 & 2.497 & 15,46 \\
\hline 13 & Kasihan & 30.403 & 3.777 & 12,42 \\
\hline 14 & Sewon & 26.375 & 3.744 & 14,20 \\
\hline 15 & Piyungan & 14.521 & 2.248 & 15,48 \\
\hline 16 & Pleret & 12.993 & 1.837 & 14,14 \\
\hline 17 & Banguntapan & 273.563 & 40.551 & 14,82 \\
\hline
\end{tabular}

Sumber : BKK PP dan KB Kabupaten Bantul 2016 (http://tkpk.bantulkab.go.id/p=82).

Berdasarkan tabel 2. diketahui bahwa persentase terbesar jumlah KK Miskin di Kabupaten Bantul terdapat di kecamatan Dlingo, Pundong dan Jetis. Sedangkan jumlah KK terbesar ada di kecamata Banguntapan berjumlah 273.463 dengan jumlah KK Miskin $14 \%$ dari total KK yang ada.

\subsection{Kajian Pustaka}

\subsubsection{Pekerja Wanita Miskin}

Dari beberapa penelitian menunjukkan bahwa ada perbedaan antara laki-laki dan wanita pekerja dalam pengaturan waktu. White dalam Susanto (2013) dalam penelitian tentang perbedaan pengaturan waktu antara laki-laki dan wanita di Kaliloro Yogyakarta menyimpulkan bahwa pekerja wanita menggunakan jam kerja yang lebih panjang daripada laki-laki, tetapi wanita lebih banyak menggunakan waktunya untuk pekerjaan rumah tangga, menjual hasil pertanian dan pekerjaan lain. Studi yang dilakukan Stoller dalam Susanto (2013), menemukan bahwa tingkat penghasilan keluarga mempengaruhi pengaturan waktu. Pekerja wanita dari keluarga yang berpenghasilan rendah cenderung menggunakan waktunya untuk aktivitas yang lebih produktif dibandingkan dengan pekerja wanita dari keluarga berpenghasilan lebih tinggi. Hull dalam Susanto (2013) dalam penelitiannya di Maguwoharjo Yogyakarta yang meneliti peranan wanita dalam aktivitas ekonomi menemukan bahwa wanita dari kelas rendah sering menghabiskan waktunya untuk pekerjaan-pekerjaan seperti mengumpulkan kayu bakar, mengambil air dari sungai untuk memasak, mencuci di sungai dan sebagainya. Sebaliknya kegiatan ibu rumah tangga dari kelas menengah sedikit dan kurang menyita waktu. Pola kerja adalah tipe aktivitas yang dilakukan secara harian oleh pekerja wanita yang melakukan satu tipe atau beragam tipe, misalnya hanya sebagai ibu rumah tangga dan pekerja di sektor pertanian (Suratiyah, 1991).

Dalam studi yang dilakukan Sajogyo (1998) melihat bahwa pola pekerjaan wanita di pedesaan Jawa Barat yang antara lain meliputi input atau tenaga kerja dari wanita dan pria pada macam- macam pekerjaan rumah tangga dan pencari nafkah, sampai seberapa jauh pola nafkah berganda yang ada dalam masyarakat itu serta pola pendapatan konsumsi rumah tangga, hal mana kiranya dapat membantu untuk lebih menjelaskan peranan wanita dalam keluarga, dan dalam masyarakat yang lebih luas.

Menurut Sajogyo (1998), pola pekerjaan biasa dipisahkan antara pola pekerjaan rumah tangga dan pola pekerjaan pencari nafkah. Pola pekerjaan rumah tangga adalah kegiatan dalam mengambil air, mencuci alat rumah tangga, mencuci pakaian, mengasuh anak, memasak (termasuk membersihkan setelah memotong bahan yang akan dimasak, 
memasak bumbu, sampai dengan memasaknya), membersihkan rumah tangga (termasuk membersihkan bagian dalam dan pekarangan, mengepel) serta kegiatan lainlain seperti membelah kayu, memasang lampu, menumbuk padi untuk keperluan rumah tangga sendiri, berbelanja dan menyetrika pakaian. Hasil penelitian tentang pola pekerjaan rumah tangga yang dilakukan di dua desa oleh Pujiyati Sajogyo ditemukan bahwa curahan kerja wanita jauh lebih tinggi dibandingkan dengan pria dalam pekerjaan rumah tangga.

Pola pekerjaan pencari nafkah (incomeearing) berdasarkan analisa curahan tenaga kerja dan alokasi waktu dapat diuraikan dalam dua tingkat yaitu, pola curahan kerja tingkat individu (pria-wanita) dan pola curahan tenaga kerja tingkat rumah tangga (Sajogyo, 1998, 130-161). Pola pekerjaan tenaga kerja tingkat individu dapat dibedakan antara pekerjaanpekerjaan pertanian dan non pertanian. Pekerjaan pertanian meliputi pekerjan usaha tani sendiri, sebagai penyakap atau penyewa, sebagai buruh tani. Pekerjaan non pertanian meliputi pekerjaan usaha sendiri sebagai manajer atau operator, sebagai buruh (di luar pertanian).

Blood dalam Susanto (2013) mengemukakan bahwa keterlibatan wanita dalam mencari nafkah di bidang pertanian maupun non pertanian pada dasarnya tidak sekedar membantu menambah penghasilan keluarga, tetapi lebih dari itu adalah untuk mempertahankan hidup (Totok, 1990: 185). Harjono dalam Susanto (2013) menyatakan bahwa di pedesaan Jawa, wanita mempunyai andil besar dalam ekonomi keluarga dalam tugas sehari- hari yang mereka lakukan di rumah dan pendapatan yang diperoleh sebagai upah kerja, baik di bidang pertanian maupun non- pertanian.

Menurut Mardikanto menyatakan, umur dari tenaga kerja wanita juga mempengaruhi terhadap curahan tenaga yang diberikan. Bagi wanita yang tergolong di dalam umur produktif kemampuan fisiknya masih memungkinkan untuk bekerja, disamping mereka harus menyelesaikan pekerjaan rumah, mereka masih mampu membantu suami dalam mencari nafkah atau bekerja pada kegiatan produksi. Dari berbagai penelitian ternyata jumlah anak juga mempengaruhi terhadap curahan waktu kerja wanita dalam berbagai bidang kegiatan dalam upaya memberi sumbangan pendapatan pada perekonomian dalam keluarga.

Totok Mardikanto (1991) menyatakan bahwa partisipasi pada berbagai kegiatan dalam upaya menunjang ekonomi keluarga, seperti di bidang pertanian, ditentukan oleh pemilikan dan penguasaan tanah. Selanjutnya Wladis, Bakir dan Manning dalam Susanto (2013), mengemukakan bahwa besar kecilnya partisipasi angkatan kerja wanita yang nantinya akan mempengaruhi pendapatan, dipengaruhi oleh berbagai faktor demografi, sosial dan ekonomi dan faktor- faktor berikut: umur, status perkawinan, tingkat pendidikan, jumlah anak, pendapatan dan penguasaan alam.

Batasan kerja wanita diartikan sebagai jumlah jam kerja yang dipakai oleh wanita untuk melakukan pekerjaan rumah tangga dan pekerjaan mencari nafkah di bidang pertanian dan non pertanian yang dihitung rata-rata per minggu.

\subsection{Metode Penelitian}

Penelitian ini menggunakan pendekatan penelitian Expost Facto, yakni penelitian yang datanya sudah terlebih dulu ada di lapangan. Tujuan dari penelitian expost facto sama dengan penelitian eksperimental yaitu keduanya memahami hubungan antar variabel berdasarkan perbedaan yang mengiringi variabel bebas dan variabel terikat tanpa intervensi langsung.

\subsubsection{Populasi dan Sampel Penelitian}

Populasi penelitian adalah jumlah keluarga miskin di kecamatan Pundong Bantul, yang mempunyai istri atau kepala keluarganya wanita. Sedangkan teknik pengambilan sampel, menggunakan teknik quota area random sampling. Sampel, ditentukan berdasarkan masing-masing desa di kecamatan Pundong, yakni desa Srihardono, desa Panjangrejo, dan desa Seloharjo. Masing-masing desa diambil 15 orang wanita dari keluarga miskin, yang ditentukan secara undian (random sampling). Jumlah sampel 45 orang (quota sampling).

\subsubsection{Teknik Pengumpulan Data}

Teknik pengumpulan

data menggunakan metode wawancara atau intervew, yakni wawancara terpimpin. Pemilihan metode wawancara mempertimbangkan kemampuan menjawab pernyataan atau pertanyaan bagi wanita miskin. Sedangkan metode pelengkapnya adalah metode observasi. Untuk menyaksikan langsung kegiatan wanita miskin di pedesaan kecamatan Pundong, baik di dalam rumah maupun di luar rumah. Dan juga digunakan metode dokumentasi untuk pengumpulan data pelengkap, terutama data penduduk dan latar belakang ekonomi keluarga.

\subsubsection{Instrumen Penelitian}

Instrumen penelitian yang digunakan dalam pengumpulan data ini berupa pedoman 
wawancara yang berisi tentang : (1) identitas subjek, meliputi agama, jumlah anak, asal pekarangan yang dimiliki, pekerjaan pokok dan sampingan, serta pendididkan. (2) tentang distribusi pekerjaan rumah tangga, (3) curahan waktu yang digunakan wanita miskin mengerjakan pekerjaan rumah tangga, (4) curahan waktu di bidang pertanian, dan non pertanian.

\subsubsection{Teknik Analisis Data}

Teknik analisis data penelitian dilakukan menggunakan teknik statistik deskriptif prosentase, dan tabulasi silang (deskriptif kuantitatif).
4.1. Hasil Penelitian Dan Pembahasan

4.1.1. Pola pekerjaan rumah tangga dan jam kerja yang digunakan wanita miskin per minggu

Rumah tangga yang dikategorikan dalam KK Miskin pada umumnya memiliki pekerjaan rumah tangga dengan kegiatan utama memasak, mencuci dan mengasuh anak. Pola ini dapat dikategorikan dalam beberapa bentuk berikut ini.

1. Pekerjaan rumah tangga yang harus dijalankan wanita miskin

Sebagaimana kegiatan rumah tangga pada umumnya, kebutuhan pokok pangan menjadi tolok ukur utama pekerjaan rumah tangga yang dilakukkan setiap manusia.

Tabel 3. Hasil Pengumpulan Data Pekerjaan Rumah Tangga Yang Harus Dijalankan Wanita Miskin Di Kecamatan Pundong

\begin{tabular}{|c|c|c|c|c|c|c|c|c|c|}
\hline \multirow[t]{2}{*}{ No } & \multirow{2}{*}{$\begin{array}{c}\text { Pekerjaan } \\
\text { Rumah Tangga }\end{array}$} & \multicolumn{2}{|c|}{$\begin{array}{c}\text { Desa } \\
\text { Panjangrejo }\end{array}$} & \multicolumn{2}{|c|}{$\begin{array}{c}\text { Desa } \\
\text { Srihardono }\end{array}$} & \multicolumn{2}{|c|}{$\begin{array}{c}\text { Desa } \\
\text { Seloharjo }\end{array}$} & \multicolumn{2}{|c|}{ Jumlah } \\
\hline & & $\mathrm{Jml}$ & $\%$ & $\mathrm{Jml}$ & $\%$ & $\mathrm{Jml}$ & $\%$ & Jml & $\%$ \\
\hline 1 & Mengasuh anak & 12 & 80 & 14 & 93 & 13 & 86,7 & 39 & 86,7 \\
\hline 2 & Memandikan anak & 4 & 26,7 & 4 & 26,7 & 4 & 26,7 & 12 & 26,7 \\
\hline 3 & Membersihkan lantai & 11 & 73 & 8 & 53 & 12 & 80 & 31 & 68,9 \\
\hline 4 & Membersihkan kamar & 14 & 93 & 12 & 80 & 12 & 80 & 38 & 84,4 \\
\hline 5 & Membersihkan Pekarangan & 6 & 40 & 5 & 33 & 5 & 33 & 16 & 35,5 \\
\hline 6 & Memasak & 15 & 100 & 15 & 100 & 15 & 100 & 45 & 100 \\
\hline 7 & Mempersiapkan keperluan suami & 13 & 86,7 & 15 & 100 & 15 & 100 & 43 & 95,5 \\
\hline 8 & Mencuci pakaian & 15 & 100 & 15 & 100 & 15 & 100 & 45 & 100 \\
\hline 9 & Membersihkan perabot rumah tangga & 4 & 26,7 & 0 & 0 & 3 & 20 & 7 & 15,5 \\
\hline 10 & Lain-lain & 0 & 0 & 2 & 13 & 2 & 13 & 4 & 9 \\
\hline
\end{tabular}

Dalam tabel 3 diatas kegiatan rumah tangga dalam bentuk pengolahan makanan (memasak) dan mencuci memiliki proporsi terbesar dalam pekerjaan rumah tangga.

2. Pekerjaan Rumah Tangga yang harus dijalankan wanita miskin dalam ukuran jam per minggu.
Dalam ukuran jam per minggu pekerjaan utama yang membutuhkan waktu paling lama adalah mengasuh anak. Hal ini ditunjukkan pada pola perkerjaan rumah tangga wanita miskin dalam ukuran jam berikut ini.

Tabel 4. Hasil pengumpulan data tentang pekerjaan rumah tangga yang harus dijalankan oleh wanita miskin, berdasarkan lamanya (jam) dalam seminggu.

\begin{tabular}{|c|l|c|c|c|c|}
\hline No Kegiatan & $\begin{array}{c}\text { Desa } \\
\text { Panjangrejo } \\
\text { (jam) }\end{array}$ & $\begin{array}{c}\text { Desa } \\
\text { Srihardono } \\
\text { (jam) }\end{array}$ & $\begin{array}{c}\text { Desa } \\
\text { Seloharjo } \\
\text { (jam) }\end{array}$ & $\begin{array}{c}\text { Jumlah } \\
\text { (jam) }\end{array}$ \\
\hline 1 & Mengasuh anak & 47,8 & 36,5 & 7,8 & 40,7 \\
\hline 2 & Memandikan anak & 7 & 7 & 8,7 & 7,6 \\
\hline 3 & Membersihkan lantai & 7 & 7,9 & 7 & 7,3 \\
\hline 4 & Membersihkan kamar & 8,9 & 7,5 & 7 & 7,8 \\
\hline 5 & Membersihkan Pekarangan & 7,5 & 7 & 7 & 7,2 \\
\hline 6 & Memasak & 9,3 & 14,59 & 14 & 12,7 \\
\hline 7 & Mempersiapkan keperluan suami & 16,8 & 14,5 & 14 & 15,1 \\
\hline 8 & Mencuci pakaian & 9,8 & 7,9 & 7,9 & 8,5 \\
\hline 9 & Membersihkan perabot rumah tangga & 7 & 0 & 7 & 4,7 \\
\hline 10 & Lain-lain & 7 & 10,5 & 10,5 & 9,3 \\
\hline
\end{tabular}

Pekerjaan rumah tangga mengasuh anak dan mempersiapkan keperluan suami menjadi pekerjaan paling membutuhkan waktu lama bagi wanita $\mathrm{KK}$ miskin berdasarkan ukuran waktu per harinya. 


\subsubsection{Beban kerja wanita miskin dan} jumlah jam dalam seminggu.

Dirinci dalam beban kerja wanita miskin dengan ukuran jumlah jam seminggu, menempatkan kegiatan yang terkait dengan pertanian menjadi pekerjaan pokok yang memiliki jumlah jam perminggu dengan gambaran data pada tabel berikut ini.

Tabel 5. Hasil Pengumpulan Data Tentang Pekerjaan di Bidang Pertanian Bagi Wanita Miskin di Kecamatan Pundong

\begin{tabular}{|c|c|c|c|c|c|c|c|c|c|}
\hline \multirow[t]{2}{*}{ No } & \multirow[t]{2}{*}{ Kegiatan } & \multicolumn{2}{|c|}{$\begin{array}{c}\text { Desa } \\
\text { Panjangrejo }\end{array}$} & \multicolumn{2}{|c|}{$\begin{array}{c}\text { Desa } \\
\text { Srihardono }\end{array}$} & \multicolumn{2}{|c|}{$\begin{array}{c}\text { Desa } \\
\text { Seloharjo }\end{array}$} & \multicolumn{2}{|c|}{ Jumlah } \\
\hline & & $\mathrm{Jml}$ & $\%$ & $\mathrm{Jml}$ & $\%$ & $\mathrm{Jml}$ & $\%$ & $\mathrm{Jml}$ & $\%$ \\
\hline 1 & Menanam padi dsb & 4 & 26,7 & 3 & 20 & 3 & 20 & 10 & 22,2 \\
\hline 2 & Menyirami tanaman di sawah & 4 & 26,7 & 3 & 20 & 3 & 20 & 10 & 22,2 \\
\hline 3 & Menyiangi tanaman di sawah & 4 & 26,7 & 3 & 20 & 3 & 20 & 10 & 22,2 \\
\hline 4 & Memupuk tanaman di sawah & 4 & 26,7 & 3 & 20 & 3 & 20 & 10 & 22,2 \\
\hline 5 & Memanen hasil tanaman di sawah & 4 & 26,7 & 3 & 20 & 3 & 20 & 10 & 22,2 \\
\hline 6 & Memproses hasil tanaman di sawah & 4 & 26,7 & 3 & 20 & 3 & 20 & 10 & 22,2 \\
\hline 7 & Menanam tumbuhan di pekarangan & 11 & 73,3 & 10 & 70 & 11 & 73,3 & 32 & 71,1 \\
\hline 8 & Menyiram tanaman di pekarangan & 11 & 73,3 & 10 & 70 & 11 & 73,3 & 32 & 71,1 \\
\hline 9 & Merabuk tumbuhan di pekarangan & 11 & 73,3 & 10 & 70 & 11 & 73,3 & 32 & 71,1 \\
\hline 10 & Memanen hasil tanaman di pekarangan & 11 & 73,3 & 10 & 70 & 11 & 73,3 & 32 & 71,1 \\
\hline 11 & $\begin{array}{l}\text { Memproses hasil tanaman di } \\
\text { pekarangan }\end{array}$ & 11 & 73,3 & 10 & 70 & 11 & 73,3 & 32 & 71,1 \\
\hline
\end{tabular}

Tabel 6. Hasil Pengumpulan Data Kegiatan Pekerjaan di Bidang Peternakan Bagi Wanita Miskin di Kecamatan Pundong

\begin{tabular}{|c|l|c|c|c|c|c|c|c|c|}
\hline \multirow{2}{*}{ No Kegiatan } & \multicolumn{2}{|c|}{$\begin{array}{c}\text { Desa } \\
\text { Panjangrejo }\end{array}$} & \multicolumn{2}{c|}{$\begin{array}{c}\text { Desa } \\
\text { Srihardono }\end{array}$} & \multicolumn{2}{c|}{$\begin{array}{c}\text { Desa } \\
\text { Seloharjo }\end{array}$} & \multicolumn{2}{c|}{ Jumlah } \\
\cline { 3 - 13 } & & Jml & $\%$ & $\mathrm{Jml}$ & $\%$ & $\mathrm{Jml}$ & $\%$ & $\mathrm{Jml}$ & $\%$ \\
\hline 1 & Memberi makanan dan minuman ternak & 10 & 66,7 & 11 & 73,3 & 12 & 80 & 33 & 73,3 \\
\hline 2 & Membersihkan kandang ternak & 8 & 53,3 & 11 & 73,3 & 12 & 80 & 31 & 68,9 \\
\hline 3 & Memberi pengobatan ternak & 1 & 7 & 2 & 13,3 & 4 & 26,7 & 7 & 15,6 \\
\hline 4 & $\begin{array}{l}\text { Memasukkan ke dalam kandang ternak } \\
\text { yang dipelihara }\end{array}$ & 6 & 40 & 8 & 53,3 & 12 & 80 & 26 & 57,8 \\
\hline 5 & Mengumpulkan hasil peternakan & 6 & 40 & 12 & 80 & 11 & 73,3 & 29 & 64,4 \\
\hline 6 & Menjual hasil peternakan & 10 & 66,7 & 12 & 80 & 12 & 80 & 34 & 75,6 \\
\hline 7 & Lain-lain & 0 & 0 & 2 & 13,3 & 4 & 26,7 & 6 & 13,3 \\
\hline
\end{tabular}

Tabel 7. Hasil Pengumpulan Data Kegiatan Sosial Yang Dijalankan Wanita Miskin Di Kecamatan Pundong

\begin{tabular}{|c|c|c|c|c|c|c|c|c|c|}
\hline \multirow[t]{2}{*}{ No } & \multirow[t]{2}{*}{ Kegiatan } & \multicolumn{2}{|c|}{$\begin{array}{c}\text { Desa } \\
\text { Panjangrejo }\end{array}$} & \multicolumn{2}{|c|}{$\begin{array}{c}\text { Desa } \\
\text { Srihardono }\end{array}$} & \multicolumn{2}{|c|}{$\begin{array}{c}\text { Desa } \\
\text { Seloharjo }\end{array}$} & \multicolumn{2}{|c|}{ Jumlah } \\
\hline & & Jml & $\%$ & $\mathrm{Jml}$ & $\%$ & $\mathrm{Jml}$ & $\%$ & Jml & $\%$ \\
\hline 1 & Mengikuti arisan & 9 & 60 & 11 & 73,3 & 12 & 80 & 32 & 71,1 \\
\hline 2 & Mengikuti posyandu & 8 & 53,3 & 3 & 20 & 6 & 40 & 17 & 37,8 \\
\hline 3 & Mengikuti rapat & 6 & 40 & 6 & 40 & 7 & 46,7 & 19 & 42,2 \\
\hline 4 & Mengikuti kegiatan kea & 11 & 73,3 & 13 & 86,7 & 14 & 93,3 & 38 & 84,4 \\
\hline 5 & Membantu pekerjaan tet & 11 & 73,3 & 14 & 93,3 & 14 & 93,3 & 39 & 86,7 \\
\hline 6 & Lain-lain & 8 & 53,3 & 11 & 73,3 & 14 & 93,3 & 33 & 73,3 \\
\hline
\end{tabular}

Tabel 8. Hasil Pengumpulan Data Kegiatan Ekonomi Yang Dijalankan Wanita Miskin Di Kecamatan Pundong

\begin{tabular}{|l|l|c|c|c|c|c|c|c|c|}
\hline \multirow{2}{*}{ No } & \multirow{2}{*}{ Kegiatan } & \multicolumn{2}{c|}{$\begin{array}{c}\text { Desa } \\
\text { Panjangrejo }\end{array}$} & \multicolumn{2}{c|}{$\begin{array}{c}\text { Desa } \\
\text { Srihardono }\end{array}$} & \multicolumn{2}{c|}{$\begin{array}{c}\text { Desa } \\
\text { Seloharjo }\end{array}$} & \multicolumn{2}{c|}{ Jumlah } \\
\cline { 3 - 10 } & & Jml & $\%$ & Jml & $\%$ & Jml & $\%$ & Jml & $\%$ \\
\hline 1 & Dagang/ bakul & 3 & 20 & 3 & 20 & 1 & 6,7 & 7 & 15,5 \\
\hline 2 & Home industry & 2 & 13,3 & 2 & 13,3 & 2 & 13,3 & 6 & 13,3 \\
\hline 3 & Karyawan swasta & 1 & 6,7 & 3 & 20 & 2 & 13,3 & 6 & 13,3 \\
\hline 4 & Jasa & 9 & 60 & 7 & 46,7 & 10 & 66,7 & 26 & 57,8 \\
\hline
\end{tabular}

Tabel 9. Hasil Pengumpulan Data Kegiatan Yang Dijalankan Wanita Miskin Dalam Bidang Pertanian Di Kecamatan Pundong

\begin{tabular}{|l|c|c|c|c|c|}
\hline No & Kegiatan & $\begin{array}{c}\text { Desa } \\
\text { Panjangrejo } \\
\text { (jam per } \\
\text { minggu) }\end{array}$ & $\begin{array}{c}\text { Desa } \\
\text { Srihardono } \\
\text { (jam per } \\
\text { minggu) }\end{array}$ & $\begin{array}{c}\text { Desa } \\
\text { Seloharjo } \\
\text { (jam per } \\
\text { minggu) }\end{array}$ & $\begin{array}{c}\text { Jumlah } \\
\text { rata-rata } \\
\text { (jam per } \\
\text { minggu) }\end{array}$ \\
\hline 1 & Menanam padi dan sebagainya & 29,7 & 28 & 28 & 28,6 \\
\hline
\end{tabular}




\begin{tabular}{|l|l|c|c|c|c|}
\hline 2 & Menyirami tanaman di sawah & 14 & 7 & 7 & 9,3 \\
\hline 3 & Menyiangi tanaman di sawah & 14 & 7 & 9,3 & 10,1 \\
\hline 4 & Merabuk tanaman di sawah & 22,7 & 7 & 7 & 12,2 \\
\hline 5 & Memanen hasil tanaman di sawah & 22,7 & 18,7 & 16,3 & 19,2 \\
\hline 6 & Memroses hasil tanaman di sawah & 28 & 21 & 14 & 21 \\
\hline 7 & Menanam tumbuhan di pekarangan & 7 & 7 & 7 & 7 \\
\hline 8 & Menyiram tanaman di pekarangan & 7 & 7 & 7 & 7 \\
\hline 9 & Merabuk tumbuhan di pekarangan & 7 & 7 & 7 & 7 \\
\hline 10 & Memanen hasil tanaman di pekarangan & 11,5 & 14 & 15,3 & 13,6 \\
\hline 11 & Memroses hasil tanaman di pekarangan & 14,6 & 22,4 & 15,3 & 17,4 \\
\hline
\end{tabular}

Tabel 10. Hasil Pengumpulan Data Pelaksanaan Pekerjaan Bidang Ternak Wanita Miskin Di Kecamatan Pundong

\begin{tabular}{|c|l|c|c|c|c|}
\hline No & Kegiatan & $\begin{array}{c}\text { Desa } \\
\text { Panjangrejo } \\
\text { (jam per } \\
\text { minggu) }\end{array}$ & $\begin{array}{c}\text { Desa } \\
\text { Srihardono } \\
\text { (jam per } \\
\text { minggu) }\end{array}$ & $\begin{array}{c}\text { Desa } \\
\text { Seloharjo } \\
\text { (jam per } \\
\text { minggu) }\end{array}$ & $\begin{array}{c}\text { Jumlah } \\
\text { rata-rata } \\
\text { (jam per } \\
\text { minggu) }\end{array}$ \\
\hline 1 & Memberi makanan dan minuman ternak & 7,7 & 8,3 & 8,2 & 8,1 \\
\hline 2 & Membersihkan kandang ternak & 7 & 8,3 & 7 & 7,4 \\
\hline 3 & Memberi pengobatan ternak & 14 & 14 & 10,2 & 12,7 \\
\hline 4 & Memasukkan ke dalam kandang ternak & 7 & 7 & 7 & 9,6 \\
\hline 5 & Mengumpulkan hasil ternak & 12 & 9,3 & 7,6 & 9,5 \\
\hline 6 & Menjual hasil ternak & 2 & 8,8 & 7,6 & 9,5 \\
\hline 7 & Lain-lain & 12,6 & 7 & 7 & 8,9 \\
\hline
\end{tabular}

Tabel 11. Hasil Pengumpulan Data Pelaksanaan Menjalankan Pekerjaan Di Bidang Sosial Wanita Miskin Di Kecamatan Pundong.

\begin{tabular}{|c|l|c|c|c|c|}
\hline No & \multicolumn{1}{|c|}{ Kegiatan } & $\begin{array}{c}\text { Desa } \\
\text { Panjangrejo } \\
\text { (jam per } \\
\text { minggu) }\end{array}$ & $\begin{array}{c}\text { Desa } \\
\text { Srihardono } \\
\text { (jam per } \\
\text { minggu) }\end{array}$ & $\begin{array}{c}\text { Desa } \\
\text { Seloharjo } \\
\text { (jam per } \\
\text { minggu) }\end{array}$ & $\begin{array}{c}\text { Jumlah } \\
\text { rata-rata } \\
\text { (jam per } \\
\text { minggu) }\end{array}$ \\
\hline 1 & Mengikuti arisan & 1,2 & 1,5 & 1,7 & 1,5 \\
\hline 2 & Mengikuti posyandu & 1,2 & 2 & 2 & 1,7 \\
\hline 3 & Mengikuti rapat & 2 & 2,2 & 1,8 & 2 \\
\hline 4 & Mengikuti kegiatan keagamaan & 8,5 & 7,2 & 7,4 & 7,7 \\
\hline 5 & Membantu pekerjaan tetangga & 2,9 & 3,2 & 3,8 & 3,3 \\
\hline 6 & Lain-lain & 3,5 & 3,8 & 3,8 & 3,8 \\
\hline
\end{tabular}

Tabel 12. Hasil Pengumpulan Data Pelaksanaan Menjalankan Pekerjaan Di Bidang Ekonomi Wanita Miskin Di Kecamatan Pundong.

\begin{tabular}{|c|l|c|c|c|c|}
\hline No & \multicolumn{1}{|c|}{ Kegiatan } & $\begin{array}{c}\text { Desa } \\
\text { Panjangrej } \\
\text { o(jam per } \\
\text { minggu) }\end{array}$ & $\begin{array}{c}\text { Desa } \\
\text { Srihardono } \\
\text { (jam per } \\
\text { minggu) }\end{array}$ & $\begin{array}{c}\text { Desa } \\
\text { Seloharjo } \\
\text { (jam per } \\
\text { minggu) }\end{array}$ & $\begin{array}{c}\text { Jumlah } \\
\text { rata-rata } \\
\text { (jam per } \\
\text { minggu) }\end{array}$ \\
\hline 1 & Dagang/ bakul & 30,3 & 30,3 & 28 & 29,5 \\
\hline 2 & Home industry & 31,5 & 31,5 & 31,5 & 31,5 \\
\hline 3 & Karyawan swasta & 35 & 32,7 & 35 & 34,2 \\
\hline 4 & Jasa & 29,5 & 29 & 28,7 & 29,1 \\
\hline
\end{tabular}

Dengan data hasil riset diatas dapat ditarik sebuah pola pekerjaan rumah tangga dalam kategori KK Miskin yang menggambarkan kegiatan baik harian, mingguan maupun bulanan dengan nilai dominan pada pekerjaan sebagai berikut:

1. Menyiram, memanam dan merabuk tanaman pertanian

2. Menjual hasil pertanian, memelihara ternak dan menjual hasil peternakan

3. Melakukan kegiatan sosial membantu pekerjaan tetangga

4. Menyediakan jasa kerumahtanggaan

\subsubsection{Pola pekerjaan rumah tangga dan lamanya per minggu yang dijalankan wanita miskin dalam menjalankan pekerjaan.}

Dalam kesimpulan analisis data di atas ditarik bahwa memasak, mencuci pakaian, menyiapkan keperluan suami dan membersihkan kamar, merupakan pekerjaan yang sangat sering dilakukan oleh subyek. Memang dalam hal ini tidak dapat terlepas dari tugas wanita pada umumnya, wanita miskin pada khususnya, yakni memasak dan mencuci pakaian termasuk menyiapkan keperluan suami serta membersihkan kamar.

\subsection{Pembahasan}


Pekerjaan wanita miskin sangat urgen dalam kehidupan rumah tangga. Walaupun dalam kondisi miskin, wanita tetap menjalankan tugas dan pekerjaannya sebagai wanita. Memasak adalah tugas untuk kepentingan keluarga yang tidak dapat ditinggalkan wanita sebagai seorang ibu rumah tangga. Termasuk juga mencuci pakaian, adalah tugas seorang ibu rumah tangga. Terlebih lagi harus menyiapkan keperluan suami sehingga suami tidak terlantar dalam menjalankan tugas dan pekerjaannya.

Demikian juga membersihkan kamarkamar harus dijalani oleh seorang ibu rumah tangga. Yang menggunakan waktu lama dalam menjalankan tugas sebagai seorang ibu rumah tangga termasuk wanita miskin adalah mengasuh anak dan mempersiapkan keperluan suami. Sebagai seorang ibu pasti wanita miskin mempunyai tanggung jawab yang berat untuk mengasuh anak atau anakanaknya juga termasuk mempersiapkan keperluan suami, sebagai tugas seorang istri.

\subsubsection{Beban kerja wanita miskin}

Pada hasil analisis data diketengahkan wanita miskin juga menjalankan kegiatan di luar tugas rumah tangga, yakni dalam bidang pertanian, peternakan, sosial dan ekonomi. Wanita miskin juga berperanan dalam ikut melaksanakan kegiatan-kegiatan dalam bidang-bidang tersebut. Dalam bidang pertanian lebih berperanan dalam pertanian tentang pengolahan tanah pekarangan, karena tanah yang dimiliki sebagian besar tanah pekarangan. Mereka lebih berperanan dalam menanam dan memperdagangkan hasil tanaman pekarangan, walaupun hasilnya tidak terlalu besar. Namun hal ini merupakan tugas seorang ibu rumah tangga dalam memberikan tambahan penghasilan walaupun hanya sedikit.

Dalam bidang peternakan lebih berperan dalam penjualan hasil ternak, walaupun tidak terlalu besar juga. Memang yang memakan banyak adalah mengobati ternak, namun dalam pemeliharaannya lebih dipentingkan untuk memberi makanan dan minuman ternak, juga tentang pemeliharaan kandang.

Pada bidang sosial, wanita miskin tetap berjiwa sosial yang tinggi, yakni banyak membantu tetangga yang mempunyai pekerjaan, tanpa menerima imbalan uang dalam bekerja membantu. Subyek juga banyak menggunakan waktu untuk mengikuti kegiatan keagamaan, untuk menyeimbangkan kebutuhan kebendaan dengan kebutuhan rohani.
Pada bidang ekonomi, wanita miskin bekerja sebagai buruh, baik buruh pertanian, maupun buruh yang diberikan pekerjaan oleh orang lain, memang yang paling banyak menyita waktu adalah subyek sebagai karyawan swasta, yang pasti harus meninggalkan rumah dengan waktu yang tidak sebentar, sehingga setiap minggunya bisa memerlukan waktu 34 jam 12 menit.

\subsection{Kesimpulan dan Saran}

Kesimpulan dari analisis data diatas yaitu Pola pekerjaan rumah tangga yang dijalankan oleh wanita miskin di kecamatan Pundong adalah memasak (100\%), mencuci pakaian (100\%), menyiapkan keperluan suami $(95,5 \%)$, mengasuh anak (86,7\%), membersihkan kamar (84,4\%). Lama menjalankan pekerjaan per minggu adalah ; mengasuh anak 40 jam 42 menit, mempersiapkan keperluan suami 15 jam 6 menit. Bidang pekerjaan yang menjadi beban bagi wanita miskin di kecamatan Pundong adalah ; (1) Bidang pertanian, menanam dan memperdagangkan hasil tanaman pekarangan $(71,1 \%)$, waktu yang diperlukan 17 jam 24 menit. (2) Bidang peternakan, menjual hasil ternak $(75,6 \%)$, waktu yang banyak diperlukan untuk pengobatan ternak 12 jam 42 menit. (3) Bidang sosial, membantu pekerjaan tetangga $(86,7 \%)$ dan waktu yang paling lama untuk kegiatan keagamaan yakni 7 jam 42 menit. (4) Bidang ekonomi, yang paling banyak dijalankan adalah bidang jasa yakni sebagai buruh baik buruh pertanian maupun pekerjaan lainnya yang ditugaskan oleh orang lain $(57,8 \%)$. Waktu yang banyak digunakan adalah untuk bekerja sebagai karyaan swasta (34 jam 12 menit).

Berdasarkan kesimpulan tersebut di atas maka disarankan hal-hal sebagai berikut : Perlu diadakan sosialisasi tentang tugas dan tanggung jawab sebagai wanita dan sebagai seorang istri dalam rumah tangga, perlu diadakan pembinaan secara rutin terhadap wanita miskin sehingga ada upaya untuk mengentaskan diri dari jurang kesmiskinan, dan pemerintah perlu memprioritaskan program untuk pemberdayaan wanita, terutama wanita miskin sebab rentan terhadap hal-hal yang negatif.

\section{Daftar Pustaka}

[1] Alam, Rizky Noor. 2017. Hilangkan Mental Miskin. Harian Media Indonesia. 5 Maret 2017. Hal 5

[2] Anonimius. 2015. Partisipasi Perempuan Bangun Desa Minim. Harian Media Indonesia. 15 Desember 2015, hal. 4 
[3] 2017. Gambaran Umum Kondisi Daerah Tentang Kemiskinan.

[4] Mardikarto, Totok. 1991. Wanita dan Keluarga. Surakarta : PT Tri Tunggal

[5] Pandia, Agnes Swetta. 2014. Kokohkan Posisi Perempuan. Harian Kompas, 21 Juli 2014, Hal. 22

[6] Susanto, Budi. 2013. Peranan Wanita Miskin. Yogyakarta : Penerbit IImu Cemerlang.

[7] Suratiyah, Ken. 1991. Wanita Kerja dan Rumah Tangga: Pengaruh Pembangunan Pertanian Terhadap Peranan Wanita Pedesaan di Daerah Istimewa Yogyakarta.
Yogyakarta : Pusat Penelitian Kependudukan UGM

[8] Sajogyo, Pujiyati. 1998. Strategi Menanggulangi Kemiskinan. Harian Republika. 4 Agustus 1998, Hal. 6

Sumber lain :

[9] http//tkpk.bantulkab.go.id/p=82. Diunduh Mei 2017

[10] Harian Kompas, 21 Juli 2014

[11] Harian Media Indonesia, 5 Maret 2017

[12] Harian Media Indonesia, 15 Desember 2015 